\title{
Skuteczność i koszty leczenia raka piersi w Polsce; podejście regionalne
}

\author{
Adam Kozierkiewicz ${ }^{1}$, Roman Topór-Mądry², \\ Andrzej Śliwczyński ${ }^{3}$, Marcin Pakulski ${ }^{3}$, Jacek Jassem ${ }^{4}$
}

\begin{abstract}
Wstęp. Rak piersi jest w Polsce jednym z najczęstszych nowotworów, a trendy epidemiologiczne sugerują rosnącą zachorowalność. Porównania międzynarodowe wskazują na pozytywną korelację między wydatkami na ochronę zdrowia a wskaźnikami 5-letniego przeżycia w nowotworach. W niniejszej pracy po raz pierwszy przedstawiono analizę korelacji wskaźników 5-letniego przeżycia wśród chorych na raka piersi z poszczególnych województw z wydatkami ponoszonymi na leczenie tych osób.
\end{abstract}

Materiał i metody. W pracy wykorzystano dane NFZ dostępne w systemie pod nazwą "Rejestr Leczenia Chorób”. Analizie poddano około 59 tysięcy chorych na raka piersi, które rozpoczęły leczenie w latach 2004-2007. Wykonano analizę porównawczą wskaźników 5-letniego przeżycia wśród tych osób oraz wydatków ponoszonych na ich leczenie w całym jego cyklu, z podziałem na poszczególne województwa.

Wyniki. Wskaźniki 5-letniego przeżycia chorych na raka piersi wzrosły w Polsce w latach 2004-2007 średnio z 73,6\% do $74,9 \%$, przy względnie dużej rozpiętości w poszczególnych województwach (wśród chorych z roku 2007 w granicach od $66 \%$ do 79\%). Stwierdzono także istotne różnice między województwami w wysokości wydatków na leczenie; wśród chorych z roku 2007 rozpiętość ta wynosiła od 23,6 do 42,8 tysięcy PLN na osobę (cały cykl leczenia). Nie zaobserwowano natomiast żadnej korelacji ani pozytywnej, ani negatywnej, pomiędzy średnią wysokością wydatków a przeżyciem 5-letnim.

Wnioski. Zestawienie danych o przeżyciach 5-letnich w całej populacji chorych na raka piersi ze średnimi wydatkami na ich leczenie w poszczególnych województwach wskazuje na brak korelacji pomiędzy średnimi wydatkami i wynikami leczenia. Przyczyny różnic w wynikach leczenia mogą być zatem zależne od innych cech, np. stadium klinicznego nowotworu w chwili rozpoczęcia leczenia czy też sposobów leczenia (treatment patterns), a równocześnie część środków przeznaczanych na świadczenia nie ma wpływu na wyniki leczenia. Pogłębienie tej analizy i zrozumienie przyczyn może się przysłużyć zmniejszeniu regionalnych nierówności w wynikach leczenia chorych na raka piersi w Polsce.

\section{Effectiveness and costs of breast cancer therapy in Poland: a regional approach}

Introduction. Breast cancer is one of the most important oncological problems in Poland, and epidemiological trends suggest it is increasing in incidence. International comparisons indicate a positive correlation between health expenditures and 5 years survival rates in cancers. This article for the first time in Poland, correlates 5 -year survival rates in with expenditures for breast cancer therapy in particular regions of Poland.

\author{
${ }^{1}$ JASPERS, Europejski Bank Inwestycyjny* \\ ${ }^{2}$ Zakład Epidemiologii \\ Instytut Zdrowia Publicznego, Collegium Medicum Uniwersytetu Jagiellońskiego \\ ${ }^{3}$ Narodowy Fundusz Zdrowia \\ ${ }^{4}$ Katedra i Klinika Onkologii i Radioterapii, Gdański Uniwersytet Medyczny
}

*Opinie wyrażone przez autora w niniejszym materiale mają charakter osobisty i mogą nie odzwierciedlać stanowiska EBI 
Materials and methods. This study is based on the National Health Fund (NHF) data, available in the Register of Diseases'Treatment system. The analysis included approximately 59,000 cases of patients who started their treatment between 2004 and 2007. We analysed 5-year survival rates among these patients versus average expenditures of the NHF for their treatment in particular regions.

Results. Five-year observed survival rates increased between 2004 and 2007 from $73.6 \%$ to $74.9 \%$, with relatively large differences between regions (66\% to $79 \%$ for 2007). The NHF expenditures in particular regions differed significantly. Among patients diagnosed in 2007 the average costs of treatment ranged from 23.600 PLN to 42.800 PLN per person (for the entire treatment cycle). No correlation between survival and expenditures was found, either positive nor negative.

Conclusions. Survival rates of breast cancer patients in the regions studied are not correlated with the average expenditures for their treatment. The differences in survival rates between regions of Poland may be due to other factors, such as tumour stage at presentation, or the treatment pattern in the regions. Not all expenditures impact on treatment efficacy. A more thorough analysis of this WHF data may aid in determining why there are decreasing regional discrepancies in care and inequalities in survival rates of breast cancer patients.

NOWOTWORY Journal of Oncology 2014; 64, 1: 24-32

Słowa kluczowe: rak piersi, przeżycie 5-letnie, koszty leczenia, nierówności w zdrowiu

Key words: breast cancer, 5-year survival rate, health expenditures, health inequalities

\section{Wstęp}

Dyskutując o efektach leczenia, klinicyści posługują się głównie pojęciem skuteczności klinicznej (efficacy), które oznacza udowodnioną w kontrolowanych warunkach klinicznych zdolność danej interwencji, leku lub procedury do osiągania założonego celu [1]. Ekonomiści z kolei skupiają się głównie na efektywności (effectiveness), która oznacza zdolność danej interwencji do osiągania celów w warunkach rzeczywistych. Ten drugi miernik, w przeciwieństwie do warunków eksperymentu klinicznego, uwzględnia całą niedoskonałość i mankamenty systemu, niedoskonałość postępowania pracowników medycznych, różnorodność i zachowania chorych, a także czynniki wynikające z wpływów otoczenia [1]. Ekonomistów interesuje także efektywność kosztowa (cost effectiveness), która wskazuje, jaka jest relacja wspomnianej efektywności do nakładów, mierzonych środkami finansowymi.

Podstawową, choć niejedyną miarą sukcesu w terapii większości nowotworów jest wieloletnie przeżycie pacjentów. W odniesieniu do większości nowotworów przyjmuje się, że 5-letnie przeżycie oznacza osiągnięcie zamierzonego celu terapii (punktu końcowego interwencji). Wskaźnik przeżycia 5-letniego może być także miernikiem skuteczności (performance) systemu opieki zdrowotnej w danym aspekcie jego działania. Miernik ten wydaje się zatem dobrym łącznikiem pomiędzy światem klinicystów a światem polityki zdrowotnej i ekonomii zdrowia.

W literaturze przedmiotu znaleźć można wiele doniesień na temat różnic w czasie przeżycia w przebiegu raka piersi. Wiele tych doniesień dotyczy czasu przeżycia chorych na poszczególne postaci raka piersi. Inne doniesienia dotyczą wyników badań klinicznych analizujących określone metody leczenia w warunkach kontrolowanych eksperymentów. Trzecia grupa prac analizuje przyczyny różnic w skuteczności leczenia i jej uwarunkowań. Doniesienia te zwykle są wynikiem badań epidemiologicznych [2], wykorzystujących dane gromadzone w celach innych niż tylko badawcze - w tym w celach rozliczeniowych, jak to ma miejsce w przypadku danych Narodowego Funduszu Zdrowia (NFZ).

Wśród czynników, które wpływają na różnice w czasie przeżycia chorych na raka piersi, najczęściej wymieniane są m.in. czas rozpoznania [3,4], status społeczno-ekonomiczny chorych [5-7] oraz dobór terapii [8-10]. Niektóre doniesienia wskazują na silny związek czasu przeżycia z doświadczeniem operującego chirurga [11-13]. Wydatki na ochronę zdrowia są na ogół pozytywnie związane z wynikami leczenia $[14,15]$. Jednocześnie jednak podobny poziom wydatków w poszczególnych krajach współistnieje z różnym poziomem wyników lub różny poziom wydatków występuje w krajach o bardzo zbliżonych wynikach [15-18]. Wśród czynników wpływających na wzrost kosztów wymienia się zaawansowane stadium kliniczne oraz stosowane leczenie, a na ich zmniejszenie - późniejszy wiek chorych i wykrycie nowotworu w badaniach przesiewowych [19-22]. Te same czynniki wpływają na wyniki leczenia, choć skala ich wpływu bywa trudna do oceny [7, 23-26].

W niniejszym opracowaniu przedstawiono wskaźniki przeżycia i wydatki na leczenie chorych na raka piersi w Polsce, starając się znaleźć zależność między tymi zmiennymi w odniesieniu do chorych zamieszkujących w poszczególnych województwach.

Wskaźniki przeżycia wylicza się zwykle na podstawie danych poszczególnych osób, obejmujących czas rozpoznania, płeć i wiek w chwili zgonu. Dla zapewnienia lepszej 
porównywalności wyników dokonywana jest standaryzacja względem prawdopodobieństwa zgonu w populacji ogólnej (relative survival rate - RSR). W niniejszym materiale zastosowano nieco inne podejście, wynikające głównie z natury źródła danych. Wskaźniki przeżycia pochodzące z baz NFZ oznaczają iloraz liczby osób, które przeżyły założoną liczbę lat od rozpoczęcia leczenia nowotworu w stosunku do wszystkich rozpoczynających leczenie $w$ danym roku i stanowią wskaźniki obserwowane. Nie zostały one skorygowane o różnice w prawdopodobieństwie zgonu w populacji ogólnej, potencjalnie występujące między województwami oraz w poszczególnych latach obserwacji.

Analizie poddano wskaźniki 5-letniego przeżycia chorych, które rozpoczęły leczenie w latach 2004-2007. Wydatki, które brano pod uwagę, stanowią wszystkie terapie i wszystkie wydatki, jakie poniósł NFZ na ich leczenie w okresie od jego rozpoczęcia do marca 2013 roku, czyli czasu pozyskania do analizy danych o wydatkach. W analizie pominięto wydatki NFZ na refundację leków aptecznych (np. hormonoterapię), wszystkie prywatne wydatki chorych oraz instytucji typu Zakład Ubezpieczeń Społecznych i pracodawcy, a także koszty pośrednie.

\section{Materiał i metody \\ Charakterystyka źródła danych}

Narodowy Fundusz Zdrowia gromadzi określony zakres danych, opisujących charakter i cel wykonania tych świadczeń. Zakres tych danych określony jest przez Ministra Zdrowia w formie rozporządzenia [27]. Z punktu widzenia niniejszej analizy najważniejszymi elementami sprawozdawanych danych były identyfikatory chorych (w tym PESEL), rozpoznanie kliniczne, oznaczone kodem klasyfikacji chorób, [28] oraz kod i nazwa świadczenia. Przetwarzanie danych odbywało się z wykorzystaniem informatycznego systemu, pierwotnie obsługującego Kasy Chorych, a od 2004 obsługującego NFZ. Jakość danych z roku 2004 jest prawdopodobnie niższa, stąd wyniki dla tego okresu należy traktować z większą ostrożnością [29].

W celu umożliwienia analiz danych związanych z onkologią w systemie informatycznym Centrali NFZ został stworzony moduł pod nazwą "Rejestr Leczenia Chorób” (RLC). System RLC wyposażony jest w interfejs pozwalający na formułowanie zapytania do bazy danych epizodów leczenia. Liczba parametrów, które można określić jako warunki wyszukiwania, jest ograniczona, jednak pozwala na przeprowadzenie wielu rodzajów analiz. Dla celów niniejszej analizy korzystano z dwóch części interfejsu, nazywanych odpowiednio:„Analiza nowotworów — wskaźniki przeżycia” oraz „Analiza nowotworów - podział geograficzny”. W efekcie możliwe było uzyskanie danych dotyczących liczby chorych w bazie NFZ, charakteryzowanych określonymi cechami, oraz kwoty wydatków NFZ poniesionych w związku z leczeniem tych chorych.
Tabela I. Liczba chorych na raka piersi wg województw, z pierwszym świadczeniem zarejestrowanym w kolejnych latach 2004-2007

\begin{tabular}{|c|c|c|c|c|}
\hline Oddział NFZ & 2004 & 2005 & 2006 & 2007 \\
\hline Dolnośląski & 1213 & 1173 & 1186 & 1250 \\
\hline Kujawsko-pomorski & 894 & 864 & 867 & 860 \\
\hline Lubelski & 1372 & 787 & 704 & 776 \\
\hline Lubuski & 307 & 351 & 375 & 390 \\
\hline Łódzki & 1073 & 1132 & 1025 & 1137 \\
\hline Małopolski & 1401 & 1132 & 1044 & 1095 \\
\hline Mazowiecki & 2375 & 2139 & 2051 & 2224 \\
\hline Opolski & 361 & 340 & 358 & 392 \\
\hline Podkarpacki & 875 & 571 & 573 & 567 \\
\hline Podlaski & 366 & 356 & 357 & 376 \\
\hline Pomorski & 820 & 906 & 815 & 887 \\
\hline Śląski & 1711 & 1954 & 1811 & 1899 \\
\hline Świętokrzyski & 452 & 440 & 433 & 468 \\
\hline Warmińsko-mazurski & 493 & 503 & 459 & 541 \\
\hline Wielkopolski & 1356 & 1386 & 1378 & 1416 \\
\hline Zachodniopomorski & 680 & 641 & 680 & 669 \\
\hline Razem & 15750 & 14675 & 14120 & 14947 \\
\hline
\end{tabular}

Źródło: dane-i-analizy.pl (na podstawie RLC NFZ)

\section{Metoda badawcza}

Z części RLC wyszczególnioną jako „Analiza nowotworów - wskaźniki przeżycia” uzyskano liczbę kobiet, u których leczenie raka piersi (C50) rozpoczęło się w latach 2004-2007, w tym liczbę tych, które przeżyły 5 lat od pierwszego epizodu leczenia. Kobiety te zostały pogrupowanie wg oddziału wojewódzkiego NFZ, na terenie którego były zameldowane lub zamieszkiwały. Z części RLC „Analiza nowotworów - podział geograficzny" uzyskano dane o kwocie wydatków ponoszonych przez NFZ w związku ze świadczeniami oznaczonymi kodem C50 i wykonanymi na rzecz tych chorych [30]. W analizie wykorzystano ostatecznie dane 59492 chorych, u których po raz pierwszy postawiono rozpoznanie w tych latach, to jest około 15 tysięcy przypadków rocznie. Liczby chorych przypadających na poszczególne województwa i lata przedstawiono w tabeli I.

Przypisanie w niniejszej analizie chorych do województw oparte było na miejscu ich zamieszkania, a nie na miejscu wykonywania świadczeń czy oddziału wojewódzkiego NFZ, który leczenie opłacał. W znacznej mierze województwo zamieszkania odpowiadało oddziałowi wojewódzkiemu, w którym chore były ubezpieczone, choć występowały tutaj pewne różnice. Podobnie przypisanie wydatków do województw odnosi się do miejsca zamieszkania chorych, a nie oddziału ubezpieczenia czy też miejsca ponoszenia wydatków (lokalizacji placówek leczących). W przypadku chorych, które w czasie leczenia zmieniły miejsce zamieszkania i zmiana ta została odnotowana w systemie informatycznym NFZ, zmienione zostało także przyporządkowanie do 
Tabela II. Odsetek 5-letnich przeżyć według województw

\begin{tabular}{|c|c|c|c|c|c|c|}
\hline Oddział NFZ & 2004 & 2005 & 2006 & 2007 & $\begin{array}{c}\text { Średnio } \\
2005-2007\end{array}$ & $\begin{array}{c}\mathrm{RSR}^{*} \\
2000-2002\end{array}$ \\
\hline Dolnośląski & $74 \%$ & $73 \%$ & $75 \%$ & $76 \%$ & $75 \%$ & $75 \%$ \\
\hline Kujawsko-pomorski & $71 \%$ & $70 \%$ & $70 \%$ & $73 \%$ & $71 \%$ & $73 \%$ \\
\hline Lubelski & $73 \%$ & $75 \%$ & $75 \%$ & $79 \%$ & $76 \%$ & $76 \%$ \\
\hline Lubuski & $73 \%$ & $74 \%$ & $72 \%$ & $78 \%$ & $75 \%$ & $77 \%$ \\
\hline Łódzki & $72 \%$ & $72 \%$ & $69 \%$ & $72 \%$ & $71 \%$ & $72 \%$ \\
\hline Małopolski & $77 \%$ & $74 \%$ & $74 \%$ & $74 \%$ & $74 \%$ & $69 \%$ \\
\hline Mazowiecki & $76 \%$ & $75 \%$ & $75 \%$ & $78 \%$ & $76 \%$ & $79 \%$ \\
\hline Opolski & $74 \%$ & $73 \%$ & $71 \%$ & $72 \%$ & $72 \%$ & $75 \%$ \\
\hline Podkarpacki & $75 \%$ & $70 \%$ & $71 \%$ & $66 \%$ & $69 \%$ & $73 \%$ \\
\hline Podlaski & $71 \%$ & $73 \%$ & $71 \%$ & $74 \%$ & $73 \%$ & $74 \%$ \\
\hline Pomorski & $73 \%$ & $73 \%$ & $74 \%$ & $77 \%$ & $75 \%$ & $76 \%$ \\
\hline Śląski & $70 \%$ & $72 \%$ & $72 \%$ & $72 \%$ & $72 \%$ & $74 \%$ \\
\hline Świętokrzyski & $71 \%$ & $73 \%$ & $71 \%$ & $71 \%$ & $72 \%$ & $71 \%$ \\
\hline Warmińsko-mazurski & $72 \%$ & $74 \%$ & $78 \%$ & $76 \%$ & $76 \%$ & $75 \%$ \\
\hline Wielkopolski & $74 \%$ & $76 \%$ & $74 \%$ & $78 \%$ & $76 \%$ & $77 \%$ \\
\hline Zachodniopomorski & $78 \%$ & $74 \%$ & $75 \%$ & $77 \%$ & $75 \%$ & $79 \%$ \\
\hline Razem & $74 \%$ & $73 \%$ & $73 \%$ & $75 \%$ & $74 \%$ & $75 \%$ \\
\hline
\end{tabular}

Źródło: dane-i-analizy.pl (na podstawie RLC NFZ i *KRN 2010) [28]

województwa. W tej sytuacji, można przypuścić, że pewna liczba chorych oraz wydatków, jakie z nimi są związane, „przemieściła” się między województwami.

Ocena tych różnic, wykonana na próbie ok. 184 tysięcy chorych leczonych w całym okresie od 1999 do 2012 roku, pozwoliła oszacować, co następuje:

- ok. 17\% wszystkich chorych na raka piersi co najmniej raz skorzystało ze świadczenia z tego powodu poza swoim województwem zamieszkania,

- wydatki poniesione poza miejscem zamieszkania danej chorej stanowiły ok. 9\% całkowitych wydatków związanych z rakiem piersi,

- województwo zamieszkania zmieniło około 0,18\% żyjącej obecnie populacji osób kiedykolwiek leczonych z powodu raka piersi.

W statystycznej analizie opisowej posłużono się średnią wydatków na osobę poniesionych w całym cyklu leczenia i liczbami oraz odsetkami chorych z 5-letnim przeżyciem na poziomie województw. Ocenę zależności przeprowadzono przy użyciu analizy korelacji Spearmana. Poziom istotności przyjęto przy $\mathrm{p}<0,05$. Całość obliczeń wykonano przy użyciu programów Excel oraz SPSS v. 20.

\section{Wyniki}

Spośród około 15 tysięcy kobiet rozpoczynających leczenie z powodu raka piersi w każdym z lat 2004-2007, po 5 latach żyło ponad 73\%. Na przestrzeni 4 lat w skali kraju odsetek 5-letnich przeżyć wzrósł o około 1,3\% (tab. II). Jest to jednak wskaźnik obserwowany, i niebiorący pod uwagę różnic w strukturze wieku i umieralności ogólnej występującej w tych województwach w poszczególnych latach. Dla porównania przedstawiono względne wskaźniki 5-letnich przeżyć (relative survival rate - RSR) z badań Krajowego Rejestru Nowotworów, obejmujące chore, które rozpoczęły leczenie w latach 2000-2002 [31].

Według danych NFZ wśród chorych z rozpoznaniem podstawowym w roku 2007 odsetek 5-letnich przeżyć był najniższy w woj. podkarpackim, a najwyższy — w woj. lubelskim. Dynamika zmian wskaźnika przeżyć w poszczególnych województwach nie jest jednorodna: w latach 2004-2007 w woj. podkarpackim, a także opolskim zanotowano spadek, podczas gdy w wielu innych województwach, zwłaszcza w lubelskim i lubuskim - wzrost wskaźników przeżyć. W większości województw zmiany 5-letnich odsetków przeżyć były niewielkie (2-3 punkty procentowe; tab. II), co może być dziełem przypadku. Są jednak województwa, w których różnice te są bardziej znaczące i ich zmiany bardziej systematyczne. Tak się dzieje w przypadku różnic między skrajnymi województwami, tj. podkarpackim i lubelskim: u chorych z roku 2007 w woj. podkarpackim odsetek 5-letnich przeżyć wyniósł 66\%, a w lubelskim — prawie 79\%. Poza tym w woj. lubelskim od roku 2004 do 2007 wskaźniki przeżycia poprawiły się o 6 punktów procentowych, zaś w podkarpackim nastąpił w tym samym czasie spadek z $75 \%$ do $66 \%$.

Szczegółowe analizy wydatków na leczenie raka piersi i ich uwarunkowań przedstawiono we wcześniejszym doniesieniu [20]. W obecnej pracy zestawiono wydatki na leczenie 
Tabela III. Średnie wydatki NFZ na leczenie u chorych na raka piersi z rozpoznaniem w kolejnych latach 2004-2007, według województw, w tysiącach złotych

\begin{tabular}{lllll}
\hline Oddział NFZ & 2004 & 2005 & 2006 & 2007 \\
\hline Dolnośląski & 20,89 & 21,65 & 22,42 & 25,04 \\
Kujawsko-pomorski & 20,29 & 20,68 & 19,75 & 25,25 \\
Lubelski & 30,45 & 24,96 & 32,75 & 42,76 \\
Lubuski & 20,78 & 26,01 & 28,80 & 34,93 \\
Łódzki & 19,79 & 22,90 & 23,83 & 30,02 \\
Małopolski & 15,29 & 20,88 & 22,27 & 23,60 \\
Mazowiecki & 25,45 & 27,41 & 32,14 & 34,81 \\
Opolski & 23,40 & 27,19 & 31,55 & 35,24 \\
Podkarpacki & 22,01 & 25,59 & 23,96 & 34,67 \\
Podlaski & 35,29 & 43,35 & 42,97 & 42,94 \\
Pomorski & 19,88 & 21,61 & 24,75 & 27,70 \\
Śląski & 20,53 & 22,11 & 24,78 & 28,01 \\
Świętokrzyski & 26,07 & 25,45 & 28,92 & 33,48 \\
Warmińsko-mazurski & 25,17 & 28,09 & 27,55 & 35,41 \\
Wielkopolski & 23,81 & 23,20 & 23,15 & 25,74 \\
Zachodniopomorski & 22,31 & 20,63 & 28,66 & 32,12 \\
Razem & $\mathbf{2 2 , 7 6}$ & $\mathbf{2 4 , 0 5}$ & $\mathbf{2 6 , 4 3}$ & $\mathbf{3 0 , 6 0}$ \\
\hline
\end{tabular}

Źródło: dane-i-analizy.pl (na podstawie RLC NFZ)

chorych z lat 2004-2007 (tab. III), stanowiące sumę wydatków na leczenie analizowanej grupy chorych od początku procesu leczenia do czasu pozyskania danych (marzec 2013). Średnie krajowe wydatki na leczenie tych chorych wynosiły od 22,76 tysięcy PLN do 30,6 tysięcy PLN. Różnice w tych wydatkach w poszczególnych województwach są znaczące, konsekwentnie najwyższe w województwie podlaskim (42,8 tysięcy w roku 2007), silnie rosnące w województwie: lubelskim (z 30,5 tysięcy w 2004 do 42,8 tysięcy w 2007), konsekwentnie niskie natomiast w województwach: małopolskim (23,6 tysięcy PLN w 2007), dolnośląskim, wielkopolskim i kujawsko-pomorskim (25,3 tysięcy PLN w roku 2007).

W analizie związku pomiędzy wskaźnikiem 5-letnich przeżyć i średnimi wydatkami na osobę przeprowadzonej na poziomie wojewódzkim za lata 2004-2007 nie wykazano istotnej zależności, co wskazuje, że różnic we wskaźnikach przeżycia nie udało się wytłumaczyć różnicami w kwocie wydatków na leczenie (współczynnik korelacji wynosił 0,$02 ; p=0,94 ;$ ryc. 1). W analogicznej analizie wykonanej dla poszczególnych lat obserwacji również obserwowano brak zależności ww. zmiennych, a współczynnik korelacji był niestabilny i zmieniał się od wartości ujemnych (-0,314 w 2004 roku) do dodatnich (0,107 w 2007 roku).

Uszeregowanie poszczególnych województw w kolejnych latach ulegało pewnym zmianom. Charakterystyczne są, wspomniane wcześniej, wysokie wydatki w województwie podlaskim, niezmiennie od 2004 do 2007 roku. W roku 2007 do poziomu województwa podlaskiego zbliżyły się wydatki w województwie lubelskim. Jednocześnie przeżycia 5-letnie w województwie podlaskim plasują się na poziomach średnich i niskich wobec podobnych wskaźników z innych województw. W tym czasie dość istotnie poprawiła się pozycja województwa lubelskiego; w roku 2007 przeżycia 5-letnie w tym województwie były najwyższe w kraju i zbliżały się do $80 \%$. Z kolei w województwie małopolskim wydatki na leczenie chorych na raka piersi były konsekwentnie niskie. W 2004 roku wydatki te były najniższe w kraju, później województwo to było w grupie o niskich wydatkach, wraz z kujawsko-pomorskim, dolnośląskim, wielkopolskim i pomorskim. W kolejnych latach, relatywnie do innych województw, spadała natomiast pozycja Małopolski w odniesieniu do 5-letnich przeżyć. O ile w roku 2004 województwo to ustępowało jedynie zachodniopomorskiemu, to w roku 2007 było już poniżej średniej krajowej. W tym czasie w podobnej z punktu widzenia wydatków Wielkopolsce przeżycia 5-letnie należały do najwyższych w kraju. W czołówce województw z najwyższymi wskaźnikami przeżyć znajdowały się, oprócz lubelskiego i wielkopolskiego, także mazowieckie, zachodniopomorskie i lubuskie.

Wykres ze średnimi wartościami wydatków oraz 5-letnich przeżyć dla chorych, które rozpoczęły leczenie w latach 2004-2007, przedstawiono na rycinie 2. Wartość średnia dla Polski (punkt „Razem”) znajduje się w centrum obszaru wykresu. Krzywa regresji jest prawie idealnie płaska, co wskazuje na brak zależności między tymi dwiema zmiennymi. Wszystkie województwa można podzielić na cztery grupy: takie, w których przy wysokim wskaźniku przeżyć 5-letnich (powyżej średniej krajowej); 1) wydatki na leczenie są względnie niskie; jak w wielkopolskim, dolnośląskim, pomorskim, małopolskim czy zachodniopomorskim, oraz 2) takie, w których wydatki są względnie wysokie; lubelskie, mazowieckie, warmińsko-mazurskie. Z drugiej strony znajdują się województwa, w których odsetek przeżyć 5-letnich jest względnie niski (poniżej średniej), a w ramach tej kategorii takie, gdzie 3) wydatki są wysokie (podlaskie, a także świętokrzyskie i opolskie), oraz 4) wydatki są niskie (kujawsko-pomorskie, łódzkie i śląskie).

\section{Dyskusja}

W przedstawionym badaniu analizie poddano 5-letnie przeżycie w populacji chorych, u których rozpoznano raka piersi w latach 2004-2007, oraz wydatki na leczenie tych chorych ponoszone przez NFZ. Przeżycia 5-letnie użyte $\mathrm{w}$ analizie nie zostały skorygowane o różnice wieku populacji tych województw. Nie dokonano także korekty na "siłę nabywczą" wydatków, co stosuje się w międzynarodowych badaniach tego typu. Nieuwzględnienie tych zmiennych w pewnym stopniu mogło wpłynąć na wynik, w szczególności na względną pozycję poszczególnych województw wobec siebie. Nie zróżnicowano także postaci raka piersi i stadiów klinicznych u leczonych chorych, co nie pozwala na 
wyciąganie jednoznacznych wniosków odnośnie przyczyn obserwowanych różnic.

Pomimo tych ograniczeń niniejsza analiza pozwala ocenić związek pomiędzy wydatkami na leczenie a osiąganymi wynikami. Ponieważ nieznana jest wysokość wydatków, którą można by uznać za „prawidłową”; przeprowadzono porównanie pomiędzy województwami, poszukując optymalnej kombinacji,"efektu”i,,nakładu”, czyli efektywności kosztowej. Analiza wykazała, że przeżycia 5-letnie na krótkiej przestrzeni 4 lat wykazują pewną poprawę, średnio w kraju o 1,3 punktu procentowego. Równocześnie różnice w przeżyciach 5-letnich wśród chorych w różnych województwach są dość znacz- ne i sięgają 5 punktów procentowych. Zmiany wysokości wskaźnika 5-letnich przeżyć z roku na rok nawet o 5 punktów procentowych sugerują ich pewną przypadkowość i interpretacja tych wyników jest trudna.W niektórych województwach istnieją jednak tendencje, które wydają się stabilne, co najmniej z perspektywy 4 lat obserwacji.

Wydatki na leczenie chorych na raka piersi ujęto „longitudinalnie", tzn. zsumowano wszystkie wydatki ponoszone od początku procesu do chwili pozyskania danych z systemu NFZ. Analiza tych wielkości pozwoliła zauważyć stopniowy wzrost wydatków w latach 2004-2007, z około 22,7 tysięcy PLN /osobę do 30,6 tysięcy/PLN na osobę. Ten wzrost był
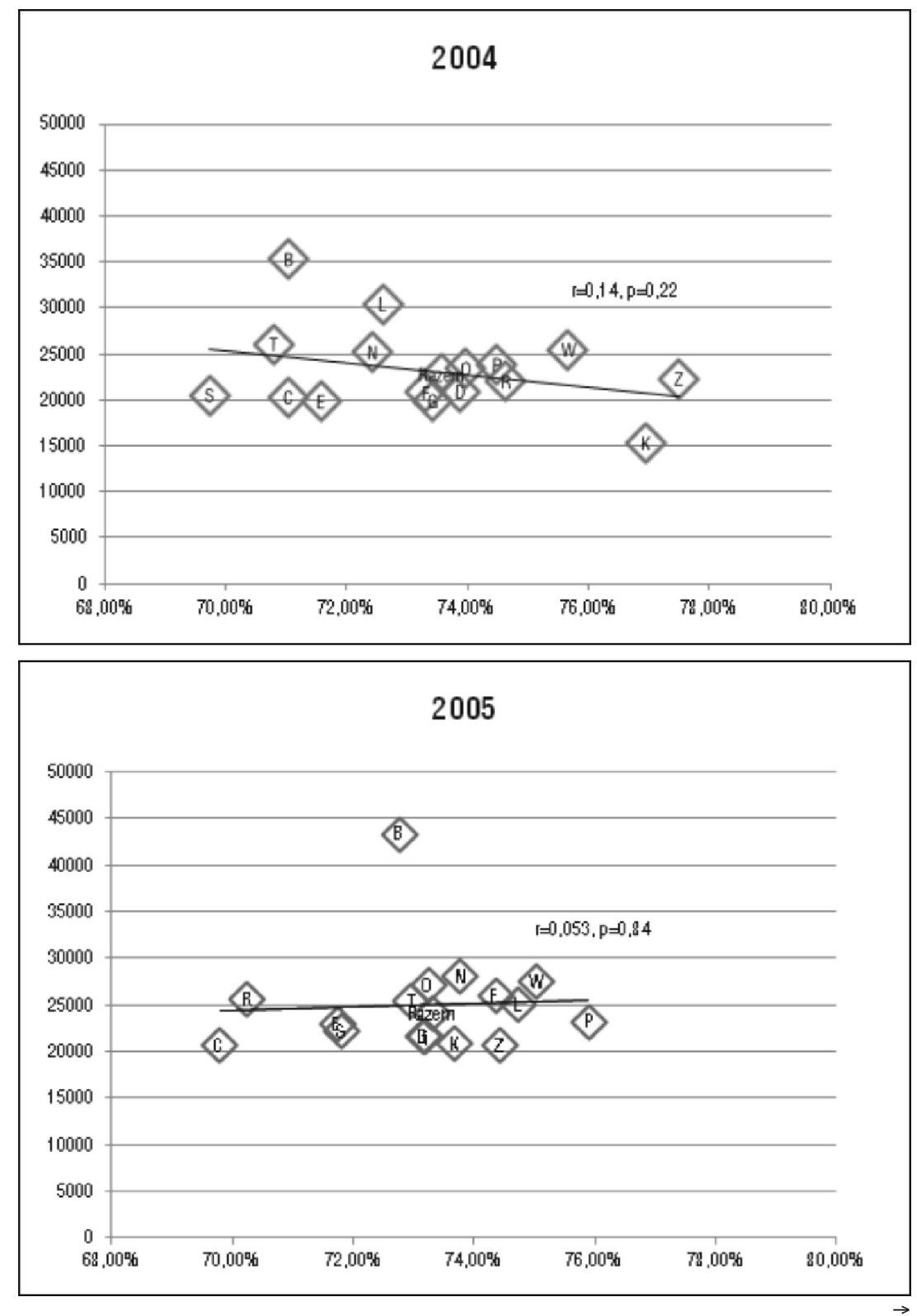

Rycina 1. Wykres zależności pomiędzy wydatkami na leczenie chorych na raka piersi a odsetkiem przeżyć 5-letnich u chorych zdaignozowanych w latach 2004-2007, według województw. Źródło: dane-i-analizy.pl (na podstawie RLC NFZ). Oznaczenie województw: D — dolnośląskie; C — kujawsko-pomorskie; L — lubelskie; F — lubuskie; E — łódzkie; K - małopolskie; W - mazowieckie; O - opolskie; R - podkarpackie; $\mathrm{B}$ - podlaskie; G — pomorskie; S - śląskie; T — świętokrzyskie; N — warmińsko-mazurskie; P — wielkopolskie; Z Z zachodniopomorskie 

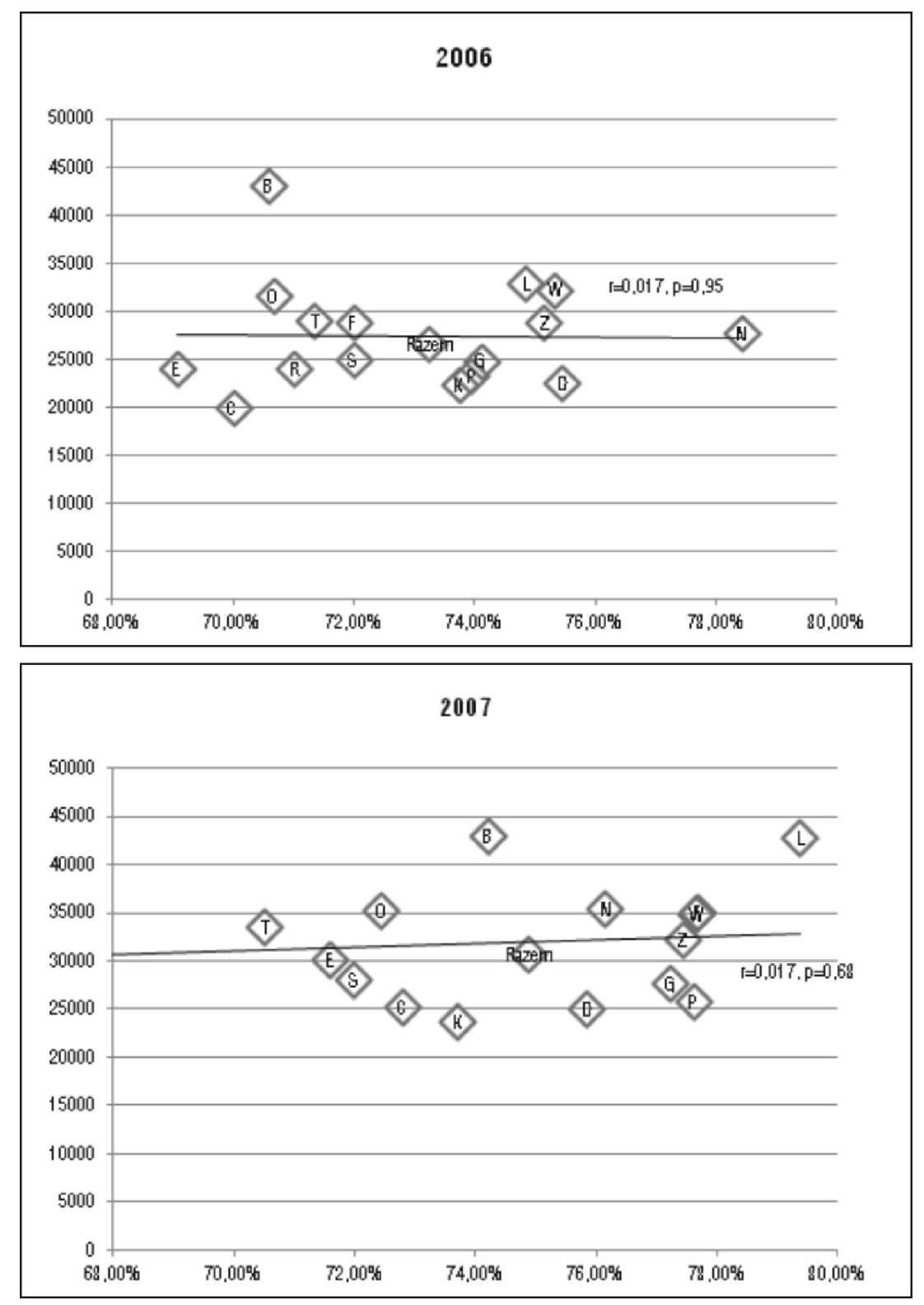

Rycina 1. cd. Wykres zależności pomiędzy wydatkami na leczenie chorych na raka piersi a odsetkiem przeżyć 5-letnich u chorych zdaignozowanych w latach 2004-2007, według województw. Źródło: dane-i-analizy.pl (na podstawie RLC NFZ). Oznaczenie województw: D — dolnośląskie; C — kujawsko-pomorskie; L — lubelskie; F — lubuskie; E — łódzkie; K — małopolskie; W - mazowieckie; O - opolskie; R — podkarpackie; B - podlaskie; G — pomorskie; S - śląskie; T — świętokrzyskie; N — warmińsko-mazurskie; P — wielkopolskie; Z zachodniopomorskie

zauważalny, pomimo że „obserwacja” wydatków dla chorych z 2004 roku jest naturalnie o 3 lata dłuższa niż dla osób z roku 2007. Z drugiej strony większość wydatków przypisanych rakowi piersi u danej osoby powstaje w pierwszych kilkunastu miesiącach od rozpoznania [29].

W obrazie wydatków szczególną pozycję zajmuje województwo podlaskie, w którym od początku obserwacji były one najwyższe. W roku 2007 do poziomu województwa podlaskiego (ok. 42 tysiące na osobę) zbliżyły się wydatki w województwie lubelskim. Pozostałe województwa wydają na leczenie podobnych chorych o około 1/3 mniej. Najniższe wydatki obserwuje się w województwie małopolskim, kujawsko-pomorskim, wielkopolskim i dolnośląskim. Wśród wymienionych czterech województw znajdują się takie, w których 5-letnie przeżycia należą do najwyższych w Polsce (wielkopolskie i dolnośląskie), a także takie, w których ten wskaźnik jest niższy (głównie kujawsko-pomorskie).

W analizie statystycznej nie wykazano zależności pomiędzy 5-letnim przeżyciem a wydatkami na leczenie chorych na raka piersi w poszczególnych województwach. Krzywa zależności jest prawie idealnie płaska, a w niektórych latach wykazywała nawet korelację negatywną (choć nieistotną statystycznie), tzn. przeżycia 5-letnie były niższe w województwach z wyższymi wydatkami. W analizie nie 


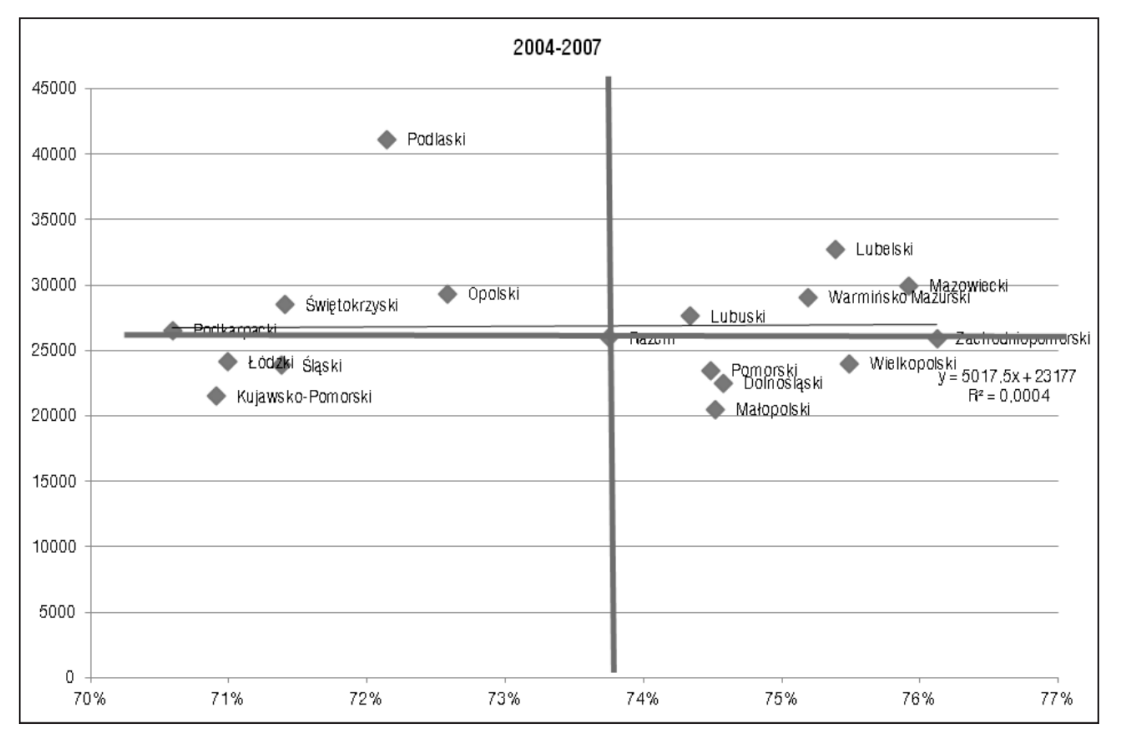

Rycina 2. Zależności pomiędzy średnimi wydatkami na leczenie raka piersi a odsetkiem 5-letnich przeżyć u chorych z rozpoznaniem w latach 2004-2007, według oddziałów NFZ dla województw. Źródło: dane-i-analizy.pl (na podstawie RLC NFZ)

uwzględniono jednak stadium klinicznego zaawansowania nowotworu; jeśli zatem w niektórych województwach stadium to byłoby średnio wyższe, to leczenie byłoby zarówno droższe, jak i mniej skuteczne. Analiza nie uwzględniała także stosowanego leczenia; przy założeniu możliwości stosowania różnych pod względem skuteczności metod może to również skutkować różnym odsetkiem przeżycia bez względu na ponoszone koszty.

Podsumowując, przeżycia 5-letnie w chorobach nowotworowych zależą od wielu czynników, wśród których poziom wydatków uznaje się za jeden z istotniejszych. Wydaje się, że większa dostępność środków powinna się przekładać na większe możliwości diagnostycznei lecznicze.W porównaniach międzynarodowych istnieje wiele dowodów na to, że taki związek rzeczywiście istnieje $[15,18]$. W obecnej analizie, opartej na rzeczywistych danych obejmujących duże grupy chorych na raka piersi w Polsce, nie udało się go jednak wykazać. Zjawisko to może wskazywać, że część środków wydatkowanych na opiekę onkologiczną przeznaczana jest na świadczenia, które nie mają wpływu na wyniki leczenia, na przykład na nadmierną hospitalizację lub niepotrzebną i często kosztowną diagnostykę. Dla dobra chorych i racjonalizacji wydatków celowe jest zatem pogłębienie tej analizy i zidentyfikowanie tych czynników.

Konflikt interesu: nie zgłoszono

\section{Dr n. med. Adam Kozierkiewicz}

ul. Drawska 14e/32, 02-202 Warszawa

e-mail:akozierkiewicz@wp.pl

Otrzymano: 26 czerwca $2013 \mathrm{r}$.

Przyjęto do druku: 1 sierpnia $2013 \mathrm{r}$.

\section{Piśmiennictwo}

1. Drummond MF, O'Brien BJ, Stoddart GL i wsp. Methods for the Economic Evaluation of Health Care Programmes, 2nd ed. Oxford University Press, Oxford-New York-Toronto 1997.

2. Pająk A, Melchior M, Kawalec E i wsp. Metody i koncepcje epidemiologiczne w zarządzaniu ochrona zdrowia. Kraków: Uniwersyteckie Wydawnictwo Medyczne „Vesalius", 2002.

3. Adami HO, Malker B, Holmberg L i wsp. The Relation between survival and age at diagnosis in breast cancer. N Engl J Med 1986; 315: 559-563.

4. Diab SG, Elledge RM, Clark GM. Tumor Characteristics and Clinical Outcome of Elderly Women With Breast Cancer. J Nat I Cancer Inst 2000; 92: 550-556.

5. Singh GK, Williams SD, Siahpush M i wsp. Socioeconomic, rural-urban, and racial inequalities in US cancer mortality: part i-all cancers and lung cancer and part II-colorectal, prostate, breast, and cervical cancers. J Cancer Epidemiol 2011: 107497. Epub 2012 Feb 14.

6. Schrijvers CT, Mackenbach JP. Cancer patient survival by socioeconomic status in seven countries: a review for six common cancer sites [corrected]. J Epidemiol Community Health 1994; 48: 441-446.

7. Downing A, Prakash K, Gilthorpe MS i wsp. Socioeconomic background in relation to stage at diagnosis, treatment and survival in women with breast cancer. Br J Cancer 2007; 96: 836-840.

8. Radice D, Redaelli A. Breast cancer management: quality-of-life and cost considerations. Pharmacoeconomics 2003; 21: 383-396.

9. Héry C, Ferlay J, Boniol M, Autier P. Changes in breast cancer incidence and mortality in middle-aged and elderly women in 28 countries with Caucasian majority populations. Ann Oncol 2008; 19: 1009-1018.

10. Debled M, Madranges N, Mertens C i wsp. First-line chemotherapy for metastatic breast cancer in patients $\geq 75$ years: A retrospective single-centre analysis. Crit Rev Oncol Hematol 2011; 80: 171-179.

11. Baak JP, Wisse-Brekelmans EC, Kurver PH i wsp. Regional differences in breast cancer survival are correlated with differences in differentiation and rate of proliferation. Hum Pathol 1992; 23: 989-992.

12. Kingsmore $D$, Hole $D$, Gillis $C$. Why does specialist treatment of breast cancer improve survival? The role of surgical management. Br J Cancer 2004; 90: 1920-1925.

13. Kingsmore D, Ssemwogerere A, Hole D, Gillis C. Specialisation and breast cancer survival in the screening era. Br J Cancer 2003; 88: 1708-1712.

14. Berrino F, De Angelis R, Sant M i wsp. Survival for eight major cancers and all cancers combined for European adults diagnosed in 1995-99: results of the EUROCARE-4 study. Lancet Oncol 2007; 8: 773-783.

15. Kozierkiewicz A, Bochenek T, Gilewski D i wsp. Biała Księga, Zwalczanie raka jelita grubego i raka piersi w Polsce na tle wybranych krajów europejskich. Warszawa-Kraków: Ośrodek Analiz Uniwersyteckich Sp. z o.o., 2011. 
16. Coleman MP, Forman D, Bryant $\mathrm{H}$ i wsp. Cancer survival in Australia, Canada, Denmark, Norway, Sweden, and the UK, 1995-2007 (the International Cancer Benchmarking Partnership): an analysis of population-based cancer registry data. Lancet $2011 ; 377$ : 127-138.

17. Yabroff KR, Lamont EB, Mariotto A i wsp. Cost of care for elderly cancer patients in the United States. J Natl Cancer Inst 2008; 100: 630-641.

18. Evans BT, Pritchard C. Cancer survival rates and GDP expenditures on health. Public Health 2000; 114: 336-339.

19. Campbell JD, Ramsey SD. The costs of treating breast cancer in the US: a synthesis of published evidence. Pharmacoeconomics 2009; 27: 199-209.

20. Kozierkiewicz A, Śliwczyński A, Pakulski M i wsp. Wydatki na leczenie raka piersi w Polsce. Nowotwory J Oncol 2013; 63: 217-226.

21. Pallis A, Tsiantou V, Simou E i wsp. Pharmacoeconomic considerations in the treatment of breast cancer. Clinicoecon Outcomes Res 2010; 2: 47-61.

22. Carles M, Vilaprinyo $\mathrm{E}$, Cots F i wsp. Cost-effectiveness of early detection of breast cancer in Catalonia (Spain). BMC Cancer 2011; 11: 192.

23. Rue $M$, Vilaprinyo $E$, Lee $S$ i wsp. Effectiveness of early detection on breast cancer mortality reduction in Catalonia (Spain). BMC Cancer 2009; 9: 326.
24. Vera-Llonch M, Weycker D, Glass A i wsp. Healthcare costs in women with metastatic breast cancer receiving chemotherapy as their principal treatment modality. BMC Cancer 2011; 11: 250.

25. John-Baptiste AA, Wu W, Rochon P i wsp. A systematic review and methodological evaluation of published cost-effectiveness analyses of aromatase inhibitors versus tamoxifen in early stage breast cancer. PLoS One 2013; 8: e62614. doi:10.1371/journal.pone.0062614.

26. Pharoah PD, Sewell B, Fitzsimmons D, Bennett HS, Pashayan N. Cost effectiveness of the NHS breast screening programme: life table model. BMJ 2013; 9: 346.

27. Rozporządzenie Ministra Zdrowia, z dnia 27 czerwca 2006 r. w sprawie zakresu niezbędnych informacji gromadzonych przez świadczeniodawców (...) Dz.U.06.114.780

28. World Health Organization. Międzynarodowa Statystyczna Klasyfikacja Chorób i Problemów Zdrowotnych, Rewizja Dziesiąta. Kraków: Fundacja Zdrowia Publicznego, 1992.

29. Kozierkiewicz A, Śliwczyński A, Jassem J i wsp. Praktyka leczenia raka piersi w Polsce. Nowotwory J Oncol 2012; 62: 250-262.

30. Didkowska J, Wojciechowska U, Kozierkiewicz A i wsp. Porównanie liczebności zbiorów. Onkol Prakt Klin 2012; 8: 129-142.

31. Wojciechowska U, Didkowska J, Zatoński W. Nowotworyzłośliwe w Polsce —wskaźniki 5 letnich przeżyćwg województw. Warszawa: Krajowy Rejestr Nowotworów, 2010.

W dniach 15-17 maja 2014 roku odbędzie się w Bydgoszczy

XX Zjazd Polskiego Towarzystwa Chirurgii Onkologicznej

\author{
Organizatorzy: \\ Polskie Towarzystwo Chirurgii Onkologicznej \\ Katedra i Klinika Chirurgii Onkologicznej CM UMK \\ Centrum Onkologii im. prof. F. Łukaszczyka w Bydgoszczy \\ Główne tematy: \\ — leczenie skojarzone nowotworów \\ — indywidualizacja leczenia onkologicznego \\ - leczenie chorych w wieku podeszłym \\ Miejsce obrad: \\ OPERA NOVA \\ ul. Focha 5, 85-070 Bydgoszcz \\ Informacja i rejestracja: \\ http://www.20zjazdptcho.pl
}

